\title{
Implementation of PMBOK 5th Standard to Improve the Performance and Competitiveness of Contractor Companies
}

\author{
Miftahul Huda $^{1}$, Soepriyono ${ }^{1}$, Siswoyo $^{1}$, Siti Azizah ${ }^{2}$ \\ \{huda.uwks@gmail.com,priyonohs@yahoo.co.id\}

\begin{abstract}
${ }^{1}$ Civil Engineering Department, University of Wijaya Kusuma Surabaya, Indonesia. ${ }^{2}$ Language and Science Department, University of Wijaya Kusuma Surabaya, Indonesia.
\end{abstract}

\begin{abstract}
As a developing country, Indonesia today has not had and implemented international standards of construction project management, such as PMBOK 5th standard, ISO 21500 or PRINCE2 which are commonly implemented by several countries. This study aimed at proving and analyzing in depth the role of construction project management standard PMBOK 5th in improving the performance and competitiveness of contractor companies in Indonesia. The study was conducted in Surabaya involving 117 respondents from directors and managers of small and medium qualified contractor companies. Data collection used Likert-Scale questionnaire instruments (1-5) with method of proportional and purposive sampling. Data analysis used SPSS and Smart PLS software. The results concluded that the implementation of project management process and project management knowledge in PMBOK 5th standard simultaneously could improve the performance and competitiveness of Indonesian contractor companies.
\end{abstract}

Keywords: management, project, performance, competitiveness, contractor, PMBOK 5th.

\section{Introduction}

The State of Indonesia as a developing country in the era of globalization is required to have construction project management standards acceptable to all countries, such as ISO 21500, PMBOK $5^{\text {th }}$ (Project Management Body of Knowledge) or PRINCE2 (Project IN Controlled Environments 2) which are the most commonly used standard currently. ISO 21500 (Tavan \& Hossaini, 2013) is a project management standard issued by ISO and initiated by the British Standard Institute in 2006 and released in 2012 as a result of a joint effort of 30 countries. PRINCE2 is a process-oriented project management method owned by AXELOS. PRINCE2 is the most common project management approach used in Europe, first published in 1990, focusing on IT projects. PRINCE was subsequently revised for general project management and released as PRINCE2 in 1996 and significantly updated in the 2009 edition. While PMBOK $5^{\text {th }}$ is one of the international standardized project managements created by the Project Management Institute (PMI). According to PMBOK $5^{\text {th }}$ project management is the application of knowledge, skills, tools and techniques in project activities to complement project needs (PMBOK $5^{\text {th }}, 2013$ ). The current PMBOK standard is the most widely used worldwide. Inside PMBOK $5^{\text {th }}$, there are two clues, namely project management process and project Management knowledge area. The project management process is a document of systematic stages of project management consisting of five stages: 1) project initiating, 2) project planning, 3) project executing stage, 4) project monitoring \& controlling stage, and 5) project closing. While the project management knowledge area of PMBOK $5^{\text {th }}$ (2013) is a document that describes the knowledge area that is within scope of the project 
management profession. The project management knowledge area consists of 10 (ten) areas, namely: 1) integration, 2) scope, 3) time, 4) cost, 5) quality, 6) human resource, 7) communication, 8) risk, 9) procurement and 10) stakeholder.

According to ISO 21500 and PMBOK 5th, there are nine project management knowledge areas and one area that is stakeholder management (Rehacek, 2014). In Table 1, it can be seen comparison between two standards. It is seen that the significant difference between PMBOK 5th (2013) and PMBOK $4^{\text {th }}(2008)$ is an additional knowledge area of stakeholder management. Based on Table 1, there is no difference between knowledge areas of PMBOK $5^{\text {th }}$ and ISO 21500. In various studies, the difference between PMBOK and PRINCE2 is based only on the process for PMBOK and on the product for PRINCE2, so the difference between them can be minimized. Some experts say that they are basically not to be compared but to complement each other because they have different approaches and goals as well as contents.

Table 1. Differences between knowledge areas of PMBK $4^{\text {th }}$, ISO 21500 , and PMBOK $5^{\text {th }}$.

\begin{tabular}{|c|c|c|c|}
\hline & $4^{\text {th }}$ PMBOK Guide & ISO 21500 & PMBOK Guide $5^{\text {th }}$ \\
\hline $\begin{array}{l}\text { Process } \\
\text { Groups }\end{array}$ & $\begin{array}{l}\text { 1. Initialing } \\
\text { 2. Planning } \\
\text { 3. Executing } \\
\text { 4. Monitoring \& } \\
\text { Controlling } \\
\text { 5. Closing } \\
\end{array}$ & $\begin{array}{l}\text { 1. Initialing } \\
\text { 2. Planning } \\
\text { 3. Implementing } \\
\text { 4. Controlling } \\
\text { 5. Closing }\end{array}$ & $\begin{array}{l}\text { 1. Initialing } \\
\text { 2. Planning } \\
\text { 3. Executing } \\
\text { 4. Monitoring \& } \\
\text { Controlling } \\
\text { 5. Closing }\end{array}$ \\
\hline $\begin{array}{l}\text { Konowledge } \\
\text { Areas }\end{array}$ & $\begin{array}{l}\text { 1. Integration } \\
\text { 2. Scope } \\
\text { 3. Time } \\
\text { 4. Cost } \\
\text { 5. Quality } \\
\text { 6. Human } \\
\text { Resource } \\
\text { 7. Communication } \\
\text { s } \\
\text { 8. Risk } \\
\text { 9. procurement }\end{array}$ & $\begin{array}{l}\text { 1. Integration } \\
\text { 2. Scope } \\
\text { 3. Time } \\
\text { 4. Cost } \\
\text { 5. Quality } \\
\text { 6. Resource } \\
\text { 7. Communication } \\
\text { S } \\
\text { 8. Risk } \\
\text { 9. Procurement } \\
\text { 10. Stakeholder }\end{array}$ & $\begin{array}{l}\text { 1. Integration } \\
\text { 2. Scope } \\
\text { 3. Time } \\
\text { 4. Cost } \\
\text { 5. Quality } \\
\text { 6. Human } \\
\text { Resource } \\
\text { 7. Communication } \\
\text { s } \\
\text { 8. Risk } \\
\text { 9. Procurement } \\
\text { 10. Stakeholder }\end{array}$ \\
\hline
\end{tabular}

The PMBOK standard aims at identifying good work and establishing common steps in construction project management (Rehacek, 2014). Thus, the PMBOK standard is identical to the competence of construction project management related to the application of knowledge, skills, tools and techniques required in handling types of construction projects (Wibowo, 2011); planning, implementing, controlling and coordinating during project implementation, to ensure that the projects have time, quality and cost planned (Husen, 2009). Isik et al. (2010) stated that the competence of construction project management is a part of the contractor's resources and capabilities. The competence of strong construction project management supported by stakeholders will support the quality of contractor strategies (Arrto et al., 2007) and improve contractor performance (Absah, 2008; Huda \& Wibowo, 2013; Isik et al., 2010; Ardiana et al, 2010).

In accordance with the development and use of construction project management standards in some countries and background of the problem described above, as well as 
research related to construction project management, competencies based on existing international standards are indispensable in Indonesia. This study was aimed at analyzing and proving the role and relationship between project management process and project management knowledge (PMBOK $5^{\text {th }}$, 2013) and also between performance and competitiveness of contractor companies. The objects of research were directors and managers of connecting companies in Surabaya, Indonesia. Variables of project management process and project management knowledge used in this study were based on the PMBOK $5^{\text {th }}$ (2013) standard.

\section{Method And Material}

\subsection{Data and Research Instrument}

This research used Likert scale instrument questionnaire (1-5). Data were collected from directors and managers of small and medium qualified contracting firms located in Surabaya and surroundings with purposive and proportional sampling techniques. Number of respondents and questioner targets required were 150 respondents. Respondents who answered and returned questionnaires were 124 respondents and 117 respondents' answers were valid and reliable. Data characteristic of respondents is shown in Table 2. Profile data of company as the sample was explained based on respondent's answer which covered aspects of company's experience, number of employees, company's average turnover per year and dominant source of project budget. This sample data is shown in Table 3, 4 and 5.

Table 2. Data Characteristics of Respondents Eligible Analysis

\begin{tabular}{|c|c|c|c|c|c|}
\hline \multirow{2}{*}{$\begin{array}{c}\text { Contractor } \\
\text { Qualification }\end{array}$} & \multirow{2}{*}{$\begin{array}{c}\text { Eligible } \\
(\%)\end{array}$} & \multicolumn{2}{|c|}{ Position of Respondent } & \multicolumn{2}{|c|}{ Gender } \\
\hline & & Director & Manager & $\mathrm{M}$ & $\mathrm{F}$ \\
\hline \multicolumn{6}{|l|}{ Small } \\
\hline S1 & 35.90 & 24 & 18 & 36 & 6 \\
\hline $\mathrm{S} 2$ & 32.48 & 33 & 5 & 34 & 4 \\
\hline S3 & 23.08 & 20 & 7 & 25 & 2 \\
\hline \multicolumn{6}{|l|}{ Medium } \\
\hline M1 & 5.98 & 2 & 5 & 6 & 1 \\
\hline M2 & 2.56 & 3 & 0 & 3 & 0 \\
\hline Total & 100 & 79 & 38 & 104 & 13 \\
\hline
\end{tabular}

Where: $\mathrm{M}=$ male, $\mathrm{F}=$ Female, $\mathrm{S} 1=$ Small grade $1, \mathrm{~S} 2=$ Small grade $2, \mathrm{~S} 3=$ Small grade 3, M1= Medium grade 1, M2= Medium grade 2

Table 3. Company Experience.

\begin{tabular}{ccccc}
\hline Experience & \multicolumn{2}{c}{ Qualification } & Total & $\begin{array}{c}\text { Percen } \\
\mathrm{t}(\%)\end{array}$ \\
\cline { 2 - 4 } & Small & $\begin{array}{c}\text { Mediu } \\
\mathrm{m}\end{array}$ & & \\
\hline$<5$ years & 22 & 0 & 21 & 17,95 \\
\hline $\begin{array}{c}6-10 \\
\text { years }\end{array}$ & 31 & 2 & 33 & 28,21 \\
\hline $\begin{array}{l}11-15 \\
\text { years }\end{array}$ & 36 & 3 & 39 & 33,33 \\
\hline
\end{tabular}




\begin{tabular}{ccccc}
\hline$>15$ years & 19 & 5 & 24 & 20,51 \\
\hline Total & 107 & 10 & 117 & 100.00 \\
\hline
\end{tabular}

Table 4. Number of permanent employees of the company.

\begin{tabular}{|c|c|c|c|c|}
\hline \multirow{2}{*}{$\begin{array}{l}\text { Number of } \\
\text { Employees }\end{array}$} & \multicolumn{2}{|c|}{ Qualification } & \multirow{2}{*}{$\begin{array}{c}\text { Tota } \\
1\end{array}$} & \multirow{2}{*}{$\begin{array}{c}\text { Percent } \\
(\%)\end{array}$} \\
\hline & Small & $\begin{array}{c}\text { Mediu } \\
\text { m }\end{array}$ & & \\
\hline$<5$ men & 20 & 0 & 20 & 17,09 \\
\hline $6-10$ man & 25 & 0 & 25 & 21,37 \\
\hline $11-15 \mathrm{man}$ & 38 & 0 & 37 & 31,62 \\
\hline 16-20 man & 18 & 2 & 20 & 17,09 \\
\hline $21-25$ man & 6 & 5 & 11 & 9,40 \\
\hline$>25$ men & 0 & 3 & 4 & 3,42 \\
\hline Total & 107 & 7 & 117 & 100 \\
\hline
\end{tabular}

Table 5: Average company revenue per year.

\begin{tabular}{|c|c|c|c|c|}
\hline \multirow{2}{*}{$\begin{array}{l}\text { Revenue (billion } \\
\text { Rupiah) }\end{array}$} & \multicolumn{2}{|c|}{ Qualification } & \multirow[t]{2}{*}{ Total } & \multirow{2}{*}{$\begin{array}{l}\text { Percen } \\
t(\%)\end{array}$} \\
\hline & Small & Medium & & \\
\hline $0-1 \mathrm{M}$ & 29 & 0 & 29 & 24,79 \\
\hline$>1 \mathrm{M}-2,5 \mathrm{M}$ & 29 & 0 & 29 & 24,79 \\
\hline$>2,5 \mathrm{M}-10 \mathrm{M}$ & 40 & 0 & 40 & 34,19 \\
\hline$>10 \mathrm{M}-25 \mathrm{M}$ & 8 & 2 & 10 & 8,55 \\
\hline$>25 \mathrm{M}-50 \mathrm{M}$ & 1 & 5 & 6 & 5,13 \\
\hline$>50 \mathrm{M}$ & 0 & 3 & 3 & 2,56 \\
\hline Total & 107 & 10 & 117 & 100.00 \\
\hline
\end{tabular}

\subsection{Modeling and Research Hypotheses}

Research variables were two independent variables and two dependent variables. Relationship of independent variables and dependent variables were based on the standard of PMBOK $5^{\text {th }}$, (2013), theoretical and empirical studies of some previous research results: research of Isik et al. (2010); Ghasem et al. (2011); Prianto et al. (2013); Huda \& Wibowo, (2013) and Huda (2017). Research Isik et al. (2010) conducted in Turkey, with respondents of large qualified contractor, concluded project management competencies based on PMBOK $4^{\text {th }}$ (2008) which had a positive and significant role to the performance of contractor companies. Research of Ghasem et al. (2011), the object of research project manager in Malaysia, concluded that some technical competences of project were to improve the quality of project manager. Prianto et al. (2013), object of the study was the competence of contractor managers in Indonesia, concluded that the competence of project managers was instrumental in the success of the construction project. Research of Huda and Wibowo (2013) on the relationship of project management competency, resources, sustainability, competitiveness performance of small-to-medium qualification contractor, concluded that project management competence on PMBOK $4^{\text {th }}$ (2008) was positively and significantly related to contractor performance improvement. Similarly, contractor performance had a positive and significant role to the competitiveness of the company.

Based on the theoretical and empirical studies above, research model is illustrated as shown in Figure 1 below. Research hypotheses is described as follows: 
1) $\mathrm{H} 1$ = Project management process had a positive and significant impact on improving project management knowledge for small and medium qualified contractor companies in Indonesia (references : PMBOK 5th (2013) and ISO 21500 (2012))

2) $\mathrm{H} 2$ = Project management knowledge had a positive and significant impact on improving the performance of small and medium qualified contractor companies in Indonesia (references : Isik et al.(2010), Ghasem et al. (2011) and Prianto et al. (2013))

3) $\mathrm{H} 3$ = Project management knowledge had a positive and significant impact on improving the competitiveness of small and medium qualified contractor companies in Indonesia (Huda \& Wibowo (2013) and Huda (2017))

4) $\mathrm{H} 4=$ firm performance had a positive and significant impact on improving the competitiveness of small and medium qualified contractor companies in Indonesia (Huda \& Wibowo (2013) and Huda (2017))

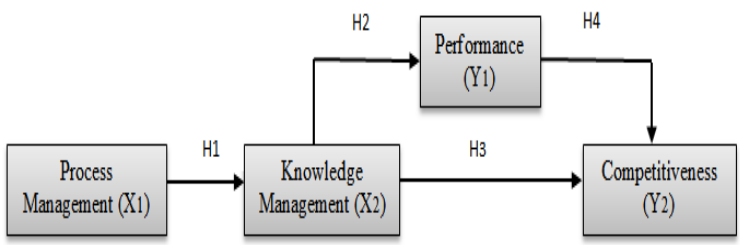

Fig. 1. Relationship of Research Variables based on PMBOK 5th and Previous Researchers.

\subsection{Definitions of Variables and Indicators}

1) Project management process (X1) was a set of construction project implementation processes consisting of several phases and sequential and related respectively. Based on the standard of project management literature ISO 21500 (2012) and PMBOK $5^{\text {th }}(2013)$, the process in project management followed project life cycle, from initiation to closing. This process was in a single phase of the project. A project consisted of various phases and each phase passed through the project management processes (Pratami et al., 2015). The project management process stage (X1) consisted of indicators: (1) Project initiating stage (X11), (2) Project planning stage (X12), (3) Project executing stage (X13), (4) Project monitoring/controlling stage (X14) and (5) Project closing stage (X15).

2) Project management knowledge (X2) was the application of various skills, abilities, knowledge and techniques required by contractor companies in handling various types of construction projects. The application is ranging from planning, implementing, controlling and coordinating from start to finish to ensure project implementation fix to the time, quality and cost planned. Project management knowledge variable was formed with 10 indicators adapted from several references, namely : Isik et al. (2010); Supriyanti et al. (2011); Ardiana et al. (2011); Ghasem et al. (2011); PMBOK 5 ${ }^{\text {th }}$ (2013), ISO 21500 (2012), Huda \& Wibowo (2013) and Benjamin \& Emmanuel (2016). Indicators of project management knowledge (X2) consisted of: (1) Integration (X21), (2) Scope (X22), (3) Time Schedule (X23), (4) Cost (X24), (5 Quality (X25), (6) Human resource (X26), (7) Communication (X27), (8) Risk (X28), (9) Procurement (X29), (10) Stakeholder (X210).

3) Company Performance (Y1): Results or achievements achieved on an ongoing basis by small and medium qualified contracting firms in comparison with objectives, standards and past achievements, in terms of financial, customer satisfaction, business processes within the company, and activities in learning and the company's growth to improve the company's financial performance in the future. The company's performance variable was 
formed with four indicators adapted from opinions; Rateb et al. (2014); Huda (2009); Isik et al. (2010); Nursin et al. (2011); Febrina (2012); Christina \& Sudana (2013); Huda \& Wibowo (2013); Waluyo (2014); Azhari et al. (2014) and Benjamin \& Emmanuel (2016). The four perspectives in the Balance Scorecard consisted of: (1) Financial Perspective (Y11), (2) Customer perspective (Y12), (3) Internal business process perspective (Y13), (4) The growth and learning perspective (Y14).

4) Company Competitiveness (Y2): competitive-ness of enterprises was ability of small and medium qualified contracting companies to compete in local and global markets, similar to the companies with all the capabilities they had. Company competitiveness variable was formed with 5 indicators adapted from opinions; Porter (2006); Roger et al. (2007); Saptana (2010); Luqman et al. (2014) ; Yong-Tao et al. (2007) and Huda \& Wibowo (2013), covering: (1) a new migrant threat (Y21), (2) bargaining power of the customer (service user) (Y22), (3) strength of suppliers' supply (Y23), (4) a new product threat (substitution) (Y24), and (5) threat of foreign contractors (Y25).

\section{Data Analysis}

\subsection{Test Validity and Reliability Instrument}

Preliminary research (20 sample respondents) was conducted to test the research instrument with validity and reliability test. Testing validity of instrument was done by looking at average value of communal, i.e. if the average value of communal was equal to 0.5 $(=0.5)$, means the indicator or item was declared valid. Instrument of test reliability was done by looking at the value of Cronbach's alpha. Reliability of measuring instrument fulfilled if the value of composite reliability was bigger than $0.7(>0.7)$. Result of validity and reliability test are shown in Table 6. Instrument of research was appropriate to be used for further research.

Table 6. Summary of Test Results on Validity \& Reliability.

\begin{tabular}{|c|c|c|c|c|}
\hline Var & Communal & Remarks & $\begin{array}{c}\text { Cronbach'sAlph } \\
\text { a }\end{array}$ & Remarks \\
\hline$(\mathrm{X} 1)$ & 0.3395 & \multirow{4}{*}{$\begin{array}{c}\text { Average } \\
0,50 \\
\text { Valid } \\
(\mathrm{OK})\end{array}$} & 0.869 & \multirow{4}{*}{$\begin{array}{c}>0.70 \\
\text { Reliable } \\
(\mathrm{OK})\end{array}$} \\
\hline$(\mathrm{X} 2)$ & 0.5653 & & 0.908 & \\
\hline (Y1) & 0.4497 & & 0.885 & \\
\hline (Y2) & 0.7302 & & 0.909 & \\
\hline
\end{tabular}

\subsection{Factor analysis}

Factor analysis was done with Smart PLS software. Result of factor analysis showed the relationship of each variable and value (coefficient) factor loading of each indicator. 


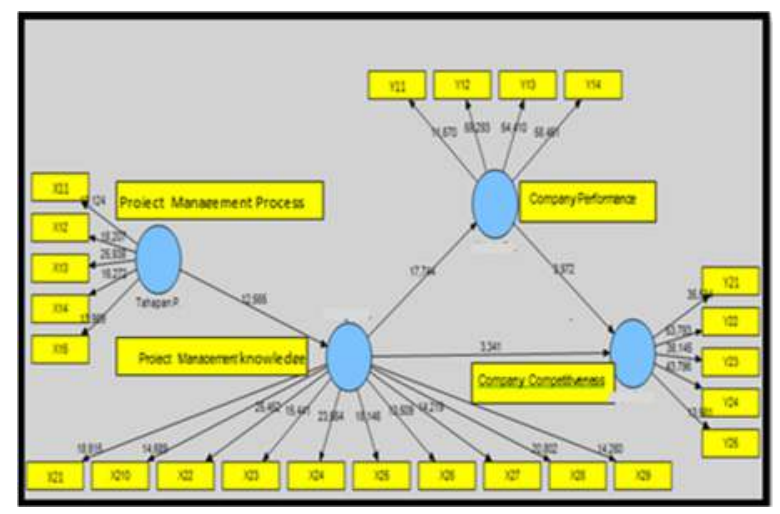

Fig. 2. Smart PLS Factor Analysis Results.

Factor loading was a coefficient generated from the evaluation of confirmatory factor analysis for the measurement model. Factor loading was used to assess the suitability, conformity or uni-dimensional of dimensions in forming a factor. Loading Factor estimation value was derived together with Loading Factor estimation results for each of variables factors against the indicators as shown in Figure 2.

\subsection{Hypotheses testing}

Hypotheses testing was done by t-test on each path of direct influence partially between latent variables. The indirect influence between latent variables was evidenced by the proof of each path of direct influence, i.e. if the whole path of direct influence was significant, then direct influence was also significant. If there was at least one indirect influence was nonsignificant, then indirect effect was non-significant. Summary of hypotheses testing results is shown in Figure 3. Hypothesis testing was done by comparing values of t-test of each latent variable with t-table $(1,96)$. The value was significant if t-test latent variable was bigger than $t$ table (t-test $>1,96)$. Hypotheses test results of each latent variable are shown in Table 7.

Table. 7 Influence between Latent Variables.

\begin{tabular}{ccccc}
\hline $\begin{array}{c}\text { Latent Variables } \\
\text { (relation) }\end{array}$ & Path Coefficient & t-test & $\begin{array}{c}\text { Criteria } \\
\text { t-test }>\text { t-table }= \\
1,96\end{array}$ \\
\hline$(\mathrm{X} 1)$ & $(\mathrm{X} 2)$ & 0,721 & 12,565 & Significant \\
\hline$(\mathrm{X} 2)$ & $(\mathrm{Y} 2)$ & 0,803 & 3,341 & Significant \\
\hline$(\mathrm{X} 2)$ & $(\mathrm{Y} 1)$ & 0,394 & 17,744 & Significant \\
\hline & $(\mathrm{Y} 2)$ & 0,464 & 9,972 & Significant \\
\hline
\end{tabular}




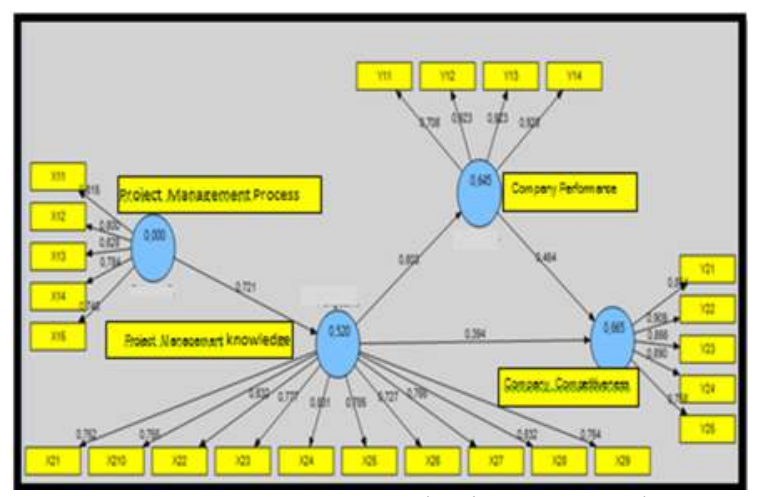

Fig. 3. Smart PLS Hypothesis Test Results.

\subsection{Influence Analysis of Latent Variables}

After research model was accepted and latent variables and indicator effects were known, influence between latent variables formed. Percentage of variance between variables and explanation is shown in Figures 3 and Table 8 . Table 8 shows R-Square value for firm competitiveness was $66,5 \%$. This result indicated percentage of company's competitiveness could be explained by independent variable of company performance. Project management knowledge variable was equal to $66,5 \%$, and the rest was equal to $33,5 \%$, explained by other independent variable. R-Square value on company performance was equal to $64,5 \%$. This meant that percentage of free variable of company performance could be explained by free variable project management knowledge equal to $64,5 \%$, and the rest was equal to $35,5 \%$, explained by other independent variable. Furthermore, R-Square value in project management competency was $52 \%$, meant that percentage of free project management knowledge variable could be explained by the free variable project management process of $52 \%$, and the remaining was $48 \%$, explained by other independent variables.

\section{Result And Discussion}

\subsection{Influence of project management process}

Project management process was a set of construction project implementation processes consisting of several phases and sequential related respectively. Based on standard of project management literature of ISO 21500 (2012) and PMBOK $5^{\text {th }}(2013)$, project management process consisted of stages: initiating, planning, executing, monitoring/ controlling and closing. Project management process was proved significantly to improve project management knowledge. So, if the contractor wanted to improve project management knowledge then the contractor should understand and implement project management process.

\subsection{Influence of project management knowledge on performance}

Project management knowledge was a kind of project management that project managers should be mastered. Based on the standard project management literature ISO 21500 (2012) and PMBOK $5^{\text {th }}(2013)$, project management knowledge area consisted of several management, namely; project integration, project scope, time or project schedule, project cost, project quality, project human resources, project communication, project risk, project procurement and project stakeholders. Project management knowledge of the area was proved 
positively and had a significant role in improving the performance of contractor companies. If the contractor companies would like to improve its competitiveness, so the contractor had to understand and implement the project management knowledge area. This study supported results of research. Rateb et al. (2014); Ghasem et al. (2011); Prianto et al. (2013) Isik et al. (2010); Supriyanti et al. (2011); Ardiana et al. (2011); PMBOK 5 ${ }^{\text {th }}$ (2013), ISO 21500 (2012), Huda \& Wibowo (2013) and Huda (2017).

\subsection{Influence of project management knowledge on competitiveness}

Project management knowledge was the kind of project management that project managers deserve. Based on the standard project management literature ISO 21500 (2012) and PMBOK 5th (2013). The project management knowledge area was proved to be positive and significant role in improving the competitiveness of contractor companies. So, if the contractor companies would like to improve its competitiveness, so the contractor should understand and implement project management knowledge area. Study results supported research results of Nursin et al. (2011); Febrina (2012); Christina \& Sudana (2013); Huda \& Wibowo (2013); Waluyo (2014) and Azhari et al. (2014).

\subsection{Influence of company performance on competitiveness}

Company performance was a result or achievement achieved continuously by small and medium qualified contractor companies in comparison with the objectives, standards and past achievements in terms of financial, customer satisfaction, business processes within the company, and activities in learning and corporate growth to improve the company's financial performance in the future. Performance variable of company was formed with 4 indicators: financial perspective, customer perspective, internal business process perspective and growth and learning perspective. Company performance had been proved to play a positive and significant role to improve the competitiveness of contractor companies. So, if the contractor companies would like to improve its competitiveness, so the contractor had to improve its performance. The results of this study supported the results of research Roger et al. (2007); Huda \& Wibowo (2013); Waluyo (2014) and Luqman et al. (2014).

Table. 8 Coefficient of Determination $\left(\mathrm{R}^{2}\right)$.

\begin{tabular}{lc}
\hline \multicolumn{1}{c}{ Latent Variable } & $\left(\mathrm{R}^{2}\right)$ \\
\hline Project management knowledge (X2) & 0,520 \\
\hline Company performance (Y2) & 0,645 \\
\hline Company competitiveness (Y2) & 0,665 \\
\hline
\end{tabular}

Table 8 explains contribution of variable project management knowledge (X2) to company performance (Y1) and competitiveness of company (Y2) was 52\%. Contribution influence of company performance (Y1) to company competitiveness was equal to $64,5 \%$. Contribution influence of company performance (Y3) and project management competence (X2) to company competitiveness (Y2) was equal to $33,1 \%$.

Results of study concluded that project management process was positively and significantly improving project management knowledge of contractor companies. Project management knowledge of contractor companies were positively and significantly improving the performance and competitiveness of contractors. Similarly, company performance was positively and significantly improving competitiveness of contractor companies. If the contractor companies would like to improve its competitiveness, so it should simultaneously 
improve project management process, project management knowledge and company performance.

\section{References}

[1] Ardiana, I.D.K. I.A. 2010. Brahmayanti, dan Subaedi. Kompetensi SDM UKM dan Penga ruhnya terhadap Kinerja UKM di Surabaya, Jurnal Manajemen dan Kewirausahaan, Vol. 12 (1) ; 42-55

[2] Azhari. Aulia, T.B. Majid, A. 2014. Risk Factors Affecting Contractor Performance on the Implementation of Infrastructure Projects in the District of Aceh Jaya. Journal of Post-Graduate Civil Engineering University of Syiah Kuala. Vol. 3, No.1, pp. 1-14.

[3] Benjamin B. A. \& Emmanuel N. J. 2016. Factors Affecting the Performance of Contractors on Building Construction Projects: Central Region, Ghana. International Journal of Innovative Researh \& Development. Vol 5 (10), pp. 151-158.

[4] Christina, N.P.Y. Sudana, I.P. 2013. Performance Assessment at PT. Adhi Karya with Balanced Scorecard Approach. E-Journal of Accounting University of Udayana. Vol. 5, No. 3, pp. 516-529.

[5] D.C.A. Butcher and M.J. Sheehan, 2010. "Excellent contractor performance in the UK construction industry," Engineering, Construction and Architectural Management, vol. 17 , pp. $35-45,2010$.

[6] Febrina, M. 2012. Perancangan Balanced Scorecard Sebagai Alat Untuk Review Strategi Perusahaan (Studi Kasus Pada Kontraktor PT. SBP di Surabaya). Jurnal Ilmiah Akuntansi. Vol. 1, No.1, pp. 97-102.

[7] Ghasem. Jaryani, F. Zafarghandi, F.J. Fattahi, S. Jamshidi. 2011. Importance Degree of Technical Competence Based on It Project Managers' Perspective, 2nd International Conference on Education and Management Technology IPEDR vol.13 (2011), IACSIT Press, Singapore.

[8] Huda, M. and Wibowo, M.A. 2013. Strategies, Performance, Sustainability and Competitiveness Model: Small and Medium Construction Services Industries in Indonesia, Journal of Basic and Applied Scientific Research, vol. 3, No. 6, pp. 741-747.

[9] Huda, M. 2009. The Influence of Environmental Factors on the Marketing Strategy and Performance of the Construction Service Industry in Indonesia, DIE - Journal of Economic and Management Scientific Research. Vol. 5, No.3. pp. 145-190.

[10] Husen, Abrar. 2009. Project Management; Project Scheduling and Control Planning: Publisher Andi Yogyakarta.

[11] Isik Z. Arditi, David. Irem Dikmen. and M. Talat Birgonul. 2010. Impact of Resources and Strategies on Construction Company Performance. Journal of Management in Engineering, Vol 26 (1); 9-18.

[12] Luqman O. O, Abimbola O. W. and Keith Stone C. 2014. Competitiveness of construction organisations in South Africa. Construction Research Congress 2014 CASCE 2014, pp. 2063-2073.

[13] Nursin, A. Wacono, S. Pratomojati, I. 2011. Construction Management Scorecard Measu-rement Model for Assessment of Performance Construction Management Project. Journal of Poly Technologies. Vol. 10. No. 1, pp. 55-67.

[14] Pratami, D. Octaviana, L. Haryono, I. 2015. Documents Design of Project Management Audit with 10 Knowledge Area of PMBOK. Edition 5. Proceeding of the $9^{\text {th }}$ Production System Seminar (2015). Study Program of Industrial Engineering, Telkom University. 
[15] Prianto, K. Dewi, S.M. 2012. The Influence of the Project Manager's Competence on the Success of the Project to the Contracting Company in the Malang District. Journal of Civil Engineering Media, Volume 10, No. 2, August 2012: pp. 156 - 168.

[16] PMBOK $^{5 \text { th }}$ 2013. Project Management Body of Knowledge. Project Management Institute. USA.

[17] Rateb J. Sweis, Sharaf M. Bisharat, Lorina Bisharat, Ghaleb Sweis. 2014. Factors Affecting Contrac tor Performance on Public Construction Projects. Life Science Journal 2014;11(4s). pp. 28-39

[18] Rehacek, Petr. 2014.Standards ISO 21500 and PMBoK Guide for Project Management. International Journal of Engineering Science and Innovative Technology (IJESIT), Vol. 3 (1); pp. 288-295.

[19] Roger, F. Weishenglu. Liyin, S and Carol Jewell. 2007.Competitiveness in construction: a critical review of research. Construction Management and Economics Journal (September 2007) 25, 989-1000

[20] Supriyanti, D. Thoyib, A. Unas, S.E. 2011. The Relevance of PMBOK 2008 to the Field of Construction Management. Brawijaya University. Journal of Civil Engineering, Vol.5 (6); pp. 201-211.

[21] Tavan \& Hossaini. 2016. Comparison and analysis of PMBOK 2013 and ISO 21500. Journal of Project Management (2016) 27-34.

[22] Waluyo, R. 2014. Relationship Model between Culture Knowledge Management and Performance in the Construction Company. Dissertation of Doctor Program (S-3) Civil Engineering, Engineering Faculty, University of Diponegoro Semarang.

[23] Wibowo, K. 2011. Factors of Competitiveness Development Strategy of Indonesia Contractor, Dissertation, Doctor Program (S-3) Civil Engineering. University of Diponegoro Semarang.

[24] Yong-Tao Tan, Li-Yin Shen, Michael C. H. Yam and Ann A. C. Lo 2017. Contractor Key Competitiveness Indicators (KCIs): a Hong Kong Study. Surveying and Built Environment Vol 18 (2), 33-46. 